\title{
Debt or Equity: An Analysis on Funding Decision (Studied of Companies of Indonesia)
}

\author{
Tettet Fitrijanti \\ Universitas Padjadjaran, Bandung, Indonesia
}

\begin{abstract}
A company leverage can be used as a proxy for capital structure of a company as a result of its funding decision. By investigating the effect of leverage deviation lag, this paper tries to examine whether or not companies in Indonesia base their funding decision on targetted leverage. Sample data are taken from non-finance companies issuing their stocks and bonds on BEI. Target leverage itself is measured by using annual average values and regression-based predicted leverage for each group of industries. The method used for the measurement is panel regression with fixed effect. Data show that, using both regression-based predicted leverage and annual average values, the actual leverage deviation for period $t$ - 1 does not affect the value of period $t$ leverage, while leverage lag on period $t-1$ does have a positive effect on period $t$ leverage. The fact that a higher lag in leverage brings about a correlatively higher leverage leads to the conclusion that funding decision and capital structure in Indonesian companies does not always conform to the Trade-Off theory, but rather corresponds well with the Pecking Order theory.
\end{abstract}

Keywords: capital structure, target leverage, leverage deviation

\section{Theoretical Background}

This paper evaluates the practice of funding decision through long-term financial leverage with the basic idea that presumably some companies in Indonesia have a tendency to set certain target leverage. Some past findings have indicated that many companies adjust their capital structure towards specific target leverage (Marsh 1982 in Hovakimian, Opler, \& Titman, 2001; Harris 1984 in Hovakimian, Opler, \& Titman 2001). It has also revealed that more profitable enterprises tend to issue debt instead of stocks to the market as their source of funds, and they are easier to repurchase their stocks than debt retirement. Collateral has, understandably, a positive effect on leverage (Rajan \& Zingales, 1995). An enterprise has a high market to book ratio issue more of their stocks on the market and has a low leverage (Shyam-Sunder \& Myers, 1999). A low cash level will refrain a company from making a decision to reducing its leverage, either by issuing their stocks on the market, or by repaying all of its debts (particularly when the sum is substantial and it is three years to the due time). This is in compliance with the Debt Overhang theory (Hovakimian, Opler, \& Titman, 2001).

According to Shyam-Sunder and Myers (1999), the Pecking Order theory could better explain the time series variation of a company's capital structure. A company having a high level of profit will be inclined to utilize its profit to repay for some of its debts, and to make the company less levered (Titman \& Wessels, 1988).

Tettet Fitrijanti, Dr., MSi., Ak., SAS, Department of Accounting, Universitas Padjadjaran.

Correspondence concerning this article should be addressed to Tettet Fitrijanti, Master of Accounting, Universitas Padjadjaran, Jl. Japati no. 4 Bandung, West Java, Indonesia. E-mail: tfitry@yahoo.com. 
A company that performs well will also be likely to be less levered (Asquith dan Mullins, 1986 in Hovakimian, Opler, \& Titman (2001, p. 1). A company having a high growth opportunity tends to have a low target to debt ratio, which is consistent with the Debt Overhang hypothesis (Myers, 1977). A manager of a company will be reluctant to issue some new stocks, or will try to raise his company's leverage when the stock price is low (Hovakimian, Opler, \& Titman, 2001, p. 3). This finding on stock return is also consistent with the view that company managers have superior private information when they are issuing or repurchasing stocks on the market (Lucas and Mc Donald, 1990, in Hovakimian, Opler, \& Titman, 2001, p. 15).

Researches on the phenomena of capital structure in Indonesia have shown considerable inconsistency among themselves. A research by Chaerul and Gina (2001) indicated that business enterprises in Indonesia tend to deal with their financial deficit through external debts, in accordance with the Pecking Order theory. A research by Dini (2004) showed that Indonesian companies have a tendency to apply targetted leverage, as predicted by the Trade-off theory, although with a slow rate of target adjustment and the fact that profitability still has a negative effect on capital structure, as predicted by the Pecking Order theory. It is summarized that profitability has a negative effect on capital structure, liquidity has a negative effect on capital structure, growth opportunity has a negative effect on capital structure, the size of a company has a positive effect on capital structure, and leverage lag has a positive effect on capital structure. A research by Freddy (2004) demonstrated that the temporal persistence of capital structure of a company and its tendency to resort to debt as its source of fund, are in accordance with the Pecking Order theory. The summary is that the market to book ratio has a positive effect on leverage, investment opportunity has a positive effect on book leverage, profitability has a negative effect on capital structure, sales does not affect on capital structure, larger companies are more dependent on external debt, companies are inclined to lower their book leverage at the moment when preceding leverage is on a high level, and lagged leverage has a negative coefficient that shows a slowing movement of leverage to its targeted value.

This paper investigates the role of target leverage as a basis for making funding decision. The research is conducted by testing capital structure through the capital structure panel regression model. A model for capital structure is intended to assess the tendency of funding decision of Indonesian companies based on their pattern of capital structure. The leverage in this research was measured by debt ratio, i.e. total debt divided by total asset. Dependent variable used in this model is the current leverage which is defined as the ratio of total debt to total asset, as is the case with the funding decision model. The author uses leverage deviation lag (actual leverage lag minus estimated leverage lag) and leverage lag as independent variables. When the target leverage is applied, leverage deviation lag and leverage lag will have a negative effect on leverage. A high value of leverage deviation lag and leverage lag in the preceding period will require the company to adjust the value of their current leverage. In the case of a company which does not apply target leverage and even continues to increase its external debt, leverage deviation lag and leverage lag do not affect, or even have a positive effect on leverage.

Target leverage is the value of leverage applied and maintained by a company after assessing the cost and benefit of an external debt. In this paper (see Table 1), target leverage is measured by using annual average values and regression-based leverage estimation. The use of least square ordinary regression (Hovakimian, 2004) using three independent variables which are also being used in the four independent variables by Hovakimian, Opler, and Titman (2001, p. 9) and a relatively large set of sample data (more than 30) can be considered as a plausible alternative. The use of average leverage per industry is based on the research carried 
by Bradley, Jarrell, \& Kim (1984) which stated that there were significant differences among the average value of leverage for different type of industries. Some of the explanatory variables used to determine regression-based target leverage in this research are delta sales income, selling expense/sales, net PPE/total asset, and firm size.

Table 1

The Operational Definition for the Capital Structure Model

\begin{tabular}{|c|c|c|c|}
\hline variable type & variables & sub-variables & indicators \\
\hline dependent & capital structure & & leverage $=$ debt ratio $=$ total debt/total aset period $t$ \\
\hline \multirow{2}{*}{ independent } & \multirow{2}{*}{ target leverage } & leverage lag & leverage period $t-1$ \\
\hline & & leverage deviation lag & (leverage_-estimated leverage) period $t-1$ \\
\hline \multirow{4}{*}{ control } & performance & & $\begin{array}{l}\text { (EBIT/Net Fixed Asset) } \\
\text { period } t-1\end{array}$ \\
\hline & under/overvalued & & $\begin{array}{l}\text { Market to Book }= \\
\text { (avg stock prices Mar-Apr period- } t \text { x total stocks in } \\
\text { circulation period-t)/ stockholder equity period } t-1\end{array}$ \\
\hline & cash level & & (cash/total asset ) period $t-1$ \\
\hline & $\begin{array}{l}\text { earning growthvs } \\
\text { earning variabilitiy }\end{array}$ & & $\begin{array}{l}\% \Delta \text { earning/earning variability }{ }^{*} \text { for the last three years } \\
(t, \ldots, t-2)\end{array}$ \\
\hline
\end{tabular}

Note. ${ }^{*}$ earning variability is measured using post-tax profit variation coefficient, that is post-tax profit standard deviation divided by average post tax profit for the last three years $(t 1, \ldots, t-2)$.

Control variables in a model for capital structure are as follows (see Table 1): operating performances measured by EBIT/net fixed asset, over/undervalued measured by market to book ratio, and level of cash measured by cash/total asset. EBIT/net fixed asset reflects the operating performance of a company, a high level of EBIT/net fixed asset makes it possible for a company to increase its external debts. For those companies which apply target leverage, a high level of operating performance will facilitate in raising the company leverage (Hovakimian, Opler, \& Titman 2001). EBIT/net fixed asset used in this research is EBIT/net fixed asset recorded one year prior to funding decision. Market to book ratio reflects the company over/undervalued state in the stock market. When the value of a company is undervalued (i.e. market to book < 1), the company management will be inclined to make funding decision that will raise the company leverage. Undervalued condition will refrain a company from issuing new stocks to the market. These phenomena are consistent with the Debt Overhang theory (Myers, 1977). In a research by Graham and Harvey (2001), it is revealed that stock over/under valuation was one of the factors that a company bears in mind in its decision for issuing new stocks. Lie (2002) in Hovakimian (2004) concluded that the level of cash was one of the determining factors in an capital structure. In a research by Graham and Harvey (2001), one of the factors that influenced the decision of a company to apply for external debts was the flexibility of its finance. In this research, it was suggested that, when a company employs a target leverage and the current level of cash is high, its funding decision will be directed to lower its leverage. The use of earning growth vs. earning variability as a control variable is based on the research by Titman dan Tsyplakov (2004) which stated that a company that had higher earning growth, compared with its volatility, will tend to have a high level of external debts, due to the fact that a company with high earning growth relative to its volatility is considered as having a good performance.

In order to obtain target leverage prior to funding decision, all of the independent variables in the multiple regression-based targel leverage model are measured one year before funding decision took place. The 
development of estimation model is done by using cross section and time series data (pooled) of the companies grouped in the same type of industry. The average leverage of these groups one year prior to funding decision will also serves as an alternative measurement for all of the companies in the same type of industry (see Table 2).

Table 2

The Non-finance Companies Listed on BEI That Are Issue Stocks and Bonds

\begin{tabular}{|c|c|c|c|c|}
\hline & EMITEN & CODE & INDUSTRY & \\
\hline 1 & BAHTERA ADIMINA SAMUDRA Tbk. & BASS & AGRICULTURE & 1 \\
\hline 2 & BAKRIE SUMATERA PLANTATION & UNSP & AGRICULTURE & 2 \\
\hline 3 & BARITO PASIFIK TBK & BRPT & BASIC INDUSTRY \& CHEMICAL & 1 \\
\hline 4 & BERLINA TBK & BRNA & CHEMICAL & 2 \\
\hline 5 & CHAROEN POKPHAND INDONESIA & CPIN & CHEMICAL & 3 \\
\hline 6 & INDAH KIAT PULP AND PAPE & INKP & CHEMICAL & 4 \\
\hline 7 & JAPFA COMFEED INDON. TBK & JPFA & CHEMICAL & 5 \\
\hline 8 & PABRIK KERTAS TJIWI KIMIA Tbk. & TKIM & CHEMICAL & 6 \\
\hline 9 & BENTOEL INTERNATIONAL INV. TBK & RMBA & CONSUMER GOODS INDUSTRY & 1 \\
\hline 10 & H.M. SAMPOERNA TBK & HMSP & CONSUMER GOODS INDUSTRY & 2 \\
\hline 11 & INDOFOOD SUKSES MAKMUR TBK & INDF & CONSUMER GOODS INDUSTRY & 3 \\
\hline 12 & KALBE FARMA TBK & KLBF & CONSUMER GOODS INDUSTRY & 4 \\
\hline 13 & MAYORA INDAH TBK & MYOR & CONSUMER GOODS INDUSTRY & 5 \\
\hline 14 & PT ULTRA DJAYA & ULTJ & CONSUMER GOODS INDUSTRY & 6 \\
\hline 15 & SUBA INDAH & SUBA & CONSUMER GOODS INDUSTRY & 7 \\
\hline 16 & BAKRIE TELECOM TBK. & BTEL & INFRASTRUCTURE UTILITY & 1 \\
\hline 17 & BERLIAN LAJU TANKER TBK & BLTA & INFRASTRUCTURE UTILITY & 2 \\
\hline 18 & CITRA MARGA NUSAPHALA TBK & CMNP & INFRASTRUCTURE UTILITY & 3 \\
\hline 19 & EXCELCOMINDO PRATAMA TBK & & INFRASTRUCTURE UTILITY & 4 \\
\hline 20 & HUMPUS INTERMODA TRANSPORTASI & MIRA & INFRASTRUCTURE UTILITY & 5 \\
\hline 21 & INDOSAT TBK & ISAT & INFRASTRUCTURE UTILITY & 6 \\
\hline 22 & JASA MARGA (PERSERO) TBK & JSMR & INFRASTRUCTURE UTILITY & 7 \\
\hline 23 & MOBILE-8 TELECOM TBK & FREN & INFRASTRUCTURE UTILITY & 8 \\
\hline 24 & PT TELEKOMUNIKASI INDONESIA & TLKM & INFRASTRUCTURE UTILITY & 9 \\
\hline 25 & ANEKA TAMBANG & ANTAM & MINING & 1 \\
\hline 26 & APEXINDO PRATAMA DUTA Tbk. & APEX & MINING & 2 \\
\hline 27 & MEDCO ENERGI INTERNASIONAL Tbk. & MEDC & MINING & 3 \\
\hline 28 & GAJAH TUNGGAL & GJTL & MISCELLANEOUS & 1 \\
\hline 29 & RICKY PUTRA GLOBALINDO TBK & RICKY & MISCELLANEOUS & 2 \\
\hline 30 & ADHI KARYA TBK & ADHI & PROPERTY \& REAL ESTATE & 1 \\
\hline 31 & BAKRIELAND DEVELOPMENT TBK & ELTY & PROPERTY \& REAL ESTATE & 2 \\
\hline 32 & BUMI SERPONG DAMAI TBK & BSDE & PROPERTY \& REAL ESTATE & 3 \\
\hline 33 & DUTA PERTIWI TBK & DUTI & PROPERTY \& REAL ESTATE & 4 \\
\hline 34 & SUMMARECON AGUNG TBK & SMRA & PROPERTY \& REAL ESTATE & 5 \\
\hline 35 & ALFA RETAIL TBK. & ALFA & TRADE MACHINE INVESTMENT & 1 \\
\hline 36 & LAUTAN LUAS TBK & LTLS & TRADE MACHINE INVESTMENT & 2 \\
\hline 37 & MATAHARI PUTRA PRIMA TBK & MPPA & TRADE MACHINE INVESTMENT & 3 \\
\hline 38 & METRODATA ELECTRONICS TBK & MTDL & TRADE MACHINE INVESTMENT & 4 \\
\hline 39 & RADIANT UTAMA INTERINSCO TBK & RUIS & TRADE MACHINE INVESTMENT & 5 \\
\hline 40 & SONA TOPAS TOURISM I. TBK & SONA & TRADE MACHINE INVESTMENT & 6 \\
\hline
\end{tabular}

Note. Source: Processed data from this research. 
Unit subjects to analysis in this research are business enterprises/private companies. Population frame is every company that are listed on BEI. Population target is every non-finance company that are listed on BEI. The subjects in this research are companies which issue their stocks and their bonds publicly on BEI (see Table 3). The time scope is a combination between time series and cross-sectional. On the whole, there are 40 non-finance companies listed on BEI that also issue their stocks and their bonds, they are classified into eight groups based on their type of industry (see Table 4). Among those companies, 28 of them have a complete set of data. The observation period is from 1999-2008, using one period of data lag. Thus the data used for model testing are taken from the period of 2000-2008.

Table 3

The Recapitulation of All Funding Decision of Samples

\begin{tabular}{|c|c|c|c|c|c|c|c|}
\hline No. & Emiten & Years & Events & Bond issued & Stocks issued & Bond buyback & Stocks buyback \\
\hline 1 & ANTAM & 4 & 4 & 1 & 1 & 1 & 1 \\
\hline 2 & BLTA & 8 & 11 & 5 & 5 & 0 & 1 \\
\hline 3 & BRNA & 3 & 4 & 2 & 2 & 0 & 0 \\
\hline 4 & BRPT & 4 & 4 & 2 & 2 & 0 & 0 \\
\hline 5 & CMNP & 5 & 6 & 3 & 2 & 1 & 0 \\
\hline 6 & CPIN & 4 & 4 & 1 & 3 & 0 & 0 \\
\hline 7 & DUTI & 7 & 8 & 4 & 3 & 1 & 0 \\
\hline 8 & ELTY & 6 & 6 & 1 & 4 & 1 & 0 \\
\hline 9 & GJTL & 4 & 6 & 2 & 4 & 0 & 0 \\
\hline 10 & HITS & 2 & 2 & 1 & 1 & 0 & 0 \\
\hline 11 & HMSP & 5 & 6 & 2 & 1 & 0 & 3 \\
\hline 12 & INDF & 10 & 12 & 4 & 3 & 2 & 3 \\
\hline 13 & INKP & 4 & 4 & 1 & 3 & 0 & 0 \\
\hline 14 & ISAT & 7 & 13 & 10 & 1 & 2 & 0 \\
\hline 15 & JPFA & 3 & 3 & 1 & 2 & 0 & 0 \\
\hline 16 & KLBF & 5 & 5 & 1 & 2 & 0 & 2 \\
\hline 17 & LTLS & 4 & 4 & 3 & 1 & 0 & 0 \\
\hline 18 & MEDC & 5 & 5 & 2 & 2 & 0 & 1 \\
\hline 19 & MPPA & 8 & 10 & 3 & 5 & 0 & 2 \\
\hline 20 & MTDL & 6 & 8 & 2 & 3 & 1 & 2 \\
\hline 21 & MYOR & 8 & 9 & 3 & 4 & 2 & 0 \\
\hline 22 & RICY & 6 & 6 & 2 & 3 & 1 & 0 \\
\hline 23 & SMRA & 5 & 6 & 3 & 3 & 0 & 0 \\
\hline 24 & SONA & 4 & 5 & 2 & 3 & 0 & 0 \\
\hline 25 & TKIM & 4 & 4 & 1 & 3 & 0 & 0 \\
\hline 26 & TLKM & 3 & 3 & 1 & 1 & 0 & 1 \\
\hline 27 & ULTJ & 5 & 8 & 3 & 4 & 1 & 0 \\
\hline 28 & UNSP & 4 & 5 & 1 & 3 & 0 & 1 \\
\hline
\end{tabular}

Note. Source: Processed data from this research.

Members of industry group are ranked based on the value of their total asset recorded on year-end finance report of 2008 (the last available period). Companies that are chose as samples have a minimum total asset of Rp 750 milliards. The reasoning is that the bigger companies in a group of companies that are in the same field of industry often represent the behavior of the group as a whole and they tend to have a relatively complete financial data that are publicly available. The quantity of financial publication of samples companies differs one 
from another. All data that can be gathered are treated as industry pooled data, so there are eight group of pooled data corresponding to the eight type of industry.

Table 4

The Number of Companies Per Industry Group for the Purpose of Determining Estimated Leverage

\begin{tabular}{lllll}
\hline NO. & INDUSTRY & COMPANIES & SAMPLES & DATA \\
\hline 1 & AGRICULTURE & 13 & 10 & 101 \\
2 & BASIC INDUSTRY \& CHEMICAL & 49 & 23 & 392 \\
3 & CONSUMER GOODS INDUSTRY & 33 & 16 & 236 \\
4 & INFRASTRUCTURE UTILITY & 25 & 18 & 192 \\
5 & MINING & 15 & 11 & 97 \\
6 & MISCELLANEOUS & 39 & 17 & 255 \\
7 & PROPERTY \& REAL ESTATE & 32 & 20 & 279 \\
8 & TRADE, SERVICES \& INVESTMENT & 67 & 27 & 362 \\
\hline SAMPLES & & 142 & \\
\hline
\end{tabular}

Note. Source: Processed data from this research.

The model for regression-based predicted leverage is as follows:

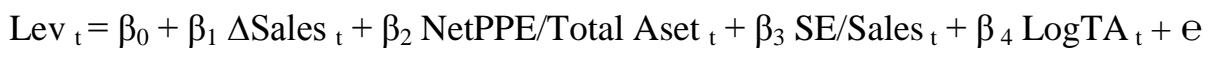

Lev $_{\mathrm{t}}=$ predicted leverage;

$\Delta \mathrm{S}_{\mathrm{t}}=$ changes in sales $\left\{\left(\right.\right.$ Sales $_{\mathrm{t}}-$ Sales $\left._{\mathrm{t}-1}\right) /$ Sales $\left._{\mathrm{t}-1}\right\}$;

$\mathrm{NPPE} / \mathrm{TA}_{\mathrm{t}}=$ net property plant \& equipment/total asset;

$\mathrm{SE} / \mathrm{S}_{\mathrm{t}}=$ Selling expense/Sales;

TA $=$ Total asset (firm size).

The model for Capital structure Fixed Effect Regression Panel:

$$
\mathrm{Lev}=\gamma_{0}+\gamma_{1} \operatorname{DevLev}_{\mathrm{it}-1}+\gamma_{2} \mathrm{Lev}_{\mathrm{it}-1}+\gamma_{3} \mathrm{KO}_{\mathrm{it}-1}+\gamma_{4} \mathrm{M} / \mathrm{B}_{\mathrm{it}-1}+\gamma_{5} \mathrm{LKas}_{\mathrm{it}-1}+\gamma_{6} \mathrm{EG}_{/} \mathrm{VR}_{\mathrm{it}-1}+\xi
$$

Lev $_{\mathrm{t}}=$ period $t$ leverage;

Lev $_{\mathrm{t}-1}=$ period $t-1$ leverage (previous year leverage);

DevLev = leverage deviation, indicated by actual leverage minus target leverage from the preceding period;

$\mathrm{KO}=$ operating performance (EBIT/Net Fixed Asset) period $t-1$;

$\mathrm{M} / \mathrm{B}=$ Market to Book ratio period $t-1$;

LKas = cash level (cash/total asset) period $t-1$;

EG/VR = earning growth/earning variability (\% change in earning period $t$ divided by earning average/standard deviation for the last three years).

Panel regression utilized the fixed effect model. The main reason for using this model is the expectation that there will be a considerable variation among the companies in their funding policies which are projected in the companies long term capital structure pattern (total cash/total asset). The model assumption is a constant slope, with varied intercepts among the sample companies. That being said, the model is a Fixed Effect Model (FEM) or Least Square Dummy Variables Model (LSDV).

This model structure is not subject to be tested by autoregressive distributed lag model, for the leverage lag variable, which is the independent variable in this model, has only one period of lag.

Combined with FEM, the model become:

$$
\begin{aligned}
\mathrm{Lev} & =\lambda_{0}+\lambda_{1} \mathrm{D}_{1 \mathrm{i}}+\lambda_{2} \mathrm{D}_{2 \mathrm{i}}+\ldots \ldots . .+\lambda_{1} \mathrm{D}_{40 \mathrm{i}}+\gamma_{1} \operatorname{DevLev}_{\mathrm{t}-1}+\gamma_{2} \operatorname{Lev}_{\mathrm{t}-1}+\gamma_{3} \mathrm{KO}_{\mathrm{t}-1}+\gamma_{4} \mathrm{M}_{\mathrm{B}} \mathrm{B}_{\mathrm{t}-1}+\gamma_{5} \mathrm{LKas}_{\mathrm{t}-1} \\
& +\gamma_{6} \mathrm{EG}_{\mathrm{E}} / \mathrm{VR}_{\mathrm{t}-1}+\xi
\end{aligned}
$$


Based on the value of the coefficient of inter-variable correlation, it was concluded that there was no moderate/strong multicollinearity between independent variables of capital structure model. Examination by Hausman Test revealed the value of prob. Chi-sq.Stat $<$ significance level $(\alpha) 5 \%$, therefore, it was concluded that the fixed effect model is a better tool than the random effect model in examining an capital structure model, whether it is predicted leverage or average. The fixed effect model testing was conducted towards average-based and regression-based models, the result of the test can be viewed on the following pages (see Tables 5 and 6).

Table 5

Tests Result for Capital Structure With Fixed Effect Regression Panel. 1. Regresion-Based Predicted Leverage

\begin{tabular}{llll}
\hline & \multicolumn{3}{c}{ Weighted Statistics } \\
\hline R-squared & 0.749485 & Mean dependent VAR. & 0.982107 \\
Adjusted R-squared & 0.711034 & S.D. dependent VAR. & 0.856201 \\
S.E. of regression & 0.161372 & Sum squared resid. & 5.598806 \\
F-statistic & 19.49185 & Durbin-Watson stat & 2.240399 \\
Prob. (F-statistic) & 0.000000 & & \\
\hline
\end{tabular}

Note. Source: Processed data from this research.

Table 6

Tests Result for Capital Structure With Fixed Effect Regression Panel. 2. Average-Based Predicted Leverage

\begin{tabular}{llll}
\hline & \multicolumn{3}{l}{ Weighted Statistics } \\
\hline R-squared & 0.722847 & Mean dependent VAR. & 0.871145 \\
Adjusted R-squared & 0.680108 & S.D. dependent VAR. & 0.679300 \\
S.E. of regression & 0.157950 & Sum squared resid. & 5.338943 \\
F-statistic & 16.91322 & Durbin-Watson stat & 2.207551 \\
Prob. (F-statistic) & 0.000000 & & \\
\hline
\end{tabular}

Note. Source: Processed data from this research.

The effect of heteroscedastisity in the testing of the fixed effect model has been minimized by conducting cross-section weighting. Referring to Granger \& Newold, it can be concluded that there is no false regression in this model. The Estimated Generalized Least Square (EGLS) method has been applied to testing in order to minimize autocorrelation.

From the result of our test towards average-based and regression-based capital structure models (see Tables 7 and 8), It can be found that the independent variable of leverage lag has a statistically significant effect on capital structure, with a significance level $\alpha 5 \%$. However, the direction affected by the leverage lag is a positive one, thereby contradicting the prediction of the Trade-Off theory.

Table 7

The Effect of Independent Variables Toward Capital Structure. 1. Regresion-Based Predicted Leverage

\begin{tabular}{|c|c|c|c|c|c|c|}
\hline C & $\begin{array}{l}\text { LAG } \\
\text { LEV }\end{array}$ & $\begin{array}{l}\text { LAG } \\
\text { DEVLEV }\end{array}$ & $\begin{array}{l}\text { LAG } \\
\text { KO }\end{array}$ & $\begin{array}{l}\text { LAG } \\
\text { KASTA }\end{array}$ & MB & $\begin{array}{l}\text { LAG } \\
\text { PRBHN } \\
\text { EARN/VAR }\end{array}$ \\
\hline $0.272364^{*}$ & $0.605962^{*}$ & -0.148439 & $-0.048539^{*}$ & -0.116926 & $-0.003492^{* *}$ & -0.000551 \\
\hline$(0.0005)$ & $(0.0000)$ & $(0.2612)$ & $(0.0005)$ & $(0.1726)$ & $(0.0955)$ & $(0.6431)$ \\
\hline Arah diharapkan & $(-)$ & $(-)$ & $(+)$ & $(-)$ & $(-)$ & $(+)$ \\
\hline
\end{tabular}

Notes. $^{*}$ : signif at $\alpha 5 \%$; ${ }^{* *}$ : signif at $\alpha 10 \%$. Source: processed data from this research. 
Table 8

The Effect of Independent Variables Toward Capital Structure. 2. Average-Based Predicted Leverage

\begin{tabular}{lllllll}
\hline C & LAG & LAG & LAG & \multirow{2}{*}{ LAG } & MB & $\begin{array}{l}\text { LAG } \\
\text { PRBHN } \\
\text { EARN/VAR }\end{array}$ \\
\hline $0.308771^{*}$ & $0.534446^{*}$ & -0.093733 & $-0.049294^{*}$ & -0.150538 & -0.00085 & -0.000508 \\
$(0.0000)$ & $(0.0000)$ & $(0.1138)$ & $(0.0010)$ & $(0.1283)$ & $(0.5882)$ & $(0.7328)$ \\
Arah diharapkan & $(-)$ & $(-)$ & $(+)$ & $(-)$ & $(-)$ & $(+)$ \\
\hline
\end{tabular}

Notes. $^{*}$ : signif at $\alpha 5 \%$. Source: Processed data from this research.

The independent variable of leverage deviation lag showed a negative effect on average-based and regression-based models, in conformity with the Trade-Off theory, but even so, with a level of significance $\alpha$ $5 \%$, the effect could be considered statistically insignificant.

The operating performance lag variable showed a significant effect on capital structure in the regression-based predicted leverage model with a significance level $\alpha 5 \%$, but its negative effect makes it inconsistent with the Trade-Off theory.

The effect of cash/total asset lag variable on capital structure in average-based and regression-based model is negative, in accordance with the Trade-Off theory. Nevertheless, with a significance level $\alpha 5 \%$, it is statistically insignificant.

The market to book variable showed a significant effect on capital structure in regression-based model, with a significance level $(\alpha) 5 \%$ and the direction of the effect is negative as expected, confirming to the Trade-Off theory.

Capital structure with the adjusted $\mathrm{R}^{2}$ fixed-effect model and a $75 \%$ regression-based predicted leverage data, therefore as much as $75 \%$ of the variation in capital structure can be explained by all of the independent variables used in regression-based predicted-leverage model. Capital structure with the adjusted $\mathrm{R}^{2}$ fixed-effect model and a $72 \%$ average-based predicted leverage data means that as much as $72 \%$ of the variation in capital structure can be explained by all of the independent variables used in average-based predicted-leverage model.

Both of the test results towards fixed-effect model generated 0.00 as the value of probability (F-statistic), smaller than $\alpha 5 \%$, therefore, both of the test results can be considered as statistically significant.

The result of the tests conducted towards capital structure with the fixed-effect model (average-based and regression-based), indicate that the actual leverage deviation from period $t-1$ predicted-leverage does not have any effect on leverage period $t$. This finding is consistent with funding decision model which stated that a lag in predicted leverage does not become a factor to be considered by most companies in making a decision on most of their funding activities, with the exception of stock buyback, espescially when there is a high lag on the companies predicted leverage.

The result of the tests conducted towards capital structure with the fixed-effect model (average-based and regression-based) also shows that leverage lag at period $t-1$ positively affects leverage at period $t$. This means that when there is a high lag in leverage, most companies will be inclined to increase their leverage. This result confirms a conclusion made by binomial and multinomial model test which states that non-finance companies in Indonesia do not consistently apply the Trade-Off theory to their funding decision. The revealed fact that the increase in leverage correlates with the increase in leverage lag, all the more reinforce the conclusion that the funding decisions made by companies in Indonesia are more in conformity with the Pecking Order theory. 


\section{Conclusions}

Actual leverage deviation from the targeted value at period $t-1$ does not have any effect on leverage value at period $t$, which means that a lag in achieving target average does not become a contributing factor for companies when making decisions regarding most of their funding activities. Leverage lag at period $t-1$ does have a positive effect on leverage at period $t$, meaning that when there is a high lag in leverage in the preceding period, the companies will tend to increase their current leverage.

\section{References}

Bradley, M., Jarrell, G. A., \& Kim, E. H. (1984, July). On the existence of an optimal capital structure: Theory and evidence. Journal of Finance, 39, 857-880.

Chaerul, D. D. \& Gina, H. (2001, September). Pecking order hypothesis analysis of jsx emitten 1994 \& 1995. Jurnal Riset Akuntansi Indonesia, 4(3), 303-313.

Dini, K. (2004). The effects of companies characteristics of capital structure, research on listed companies on JSX (Doctoral dissertation, University of Padjadjaran). Doctor Program of Manajemen Bussines of University of Padjadjaran.

Freddy, D. (2004). The effects of financing activities on persistensi of capital structure of listed non financial companies after IPO. (Doctoral dissertation, University of Padjadjaran). Doctor Program of Manajemen Bussines of University of Padjadjaran.

Graham, J. R., \& Campbell, R. H. (2001). The theory and practice of corporate finance: evidence from the field. Journal of Financial Economics, 60, 187-243.

Hovakimian, A. (2004, October). The role of target leverage in security issues and repurchases. The Journal of Business, 77(4), 1041-1071.

Hovakimian, A., Opler, T., \& Titman, S. (2001). The debt equity choice. Journal of Financial and Quantitative Analysis, XXXVI (1), 1-24.

Myers, S. C. (1977, November). Determinant of corporate borrowing. Journal of Financial Economics, 5, 147-175.

Rajan, R. G. \& Zingales, L. (1995, December). What do we know about capital structure? Some evidence from international data. Journal of Finance, 50(5), 1421-1460.

Shyam-Sunder, L., \& Myers, S. C. (1999, February). Testing static trade-off against pecking order models of capital structure. Journal of Financial Economics, 51, 219-244.

Titman, S., \& Tsyplakov, S. (2004). A dynamic model of optimal capital. 2004 Meeting Papers 549, Society for Economic Dynamics.

Titman, S., \& Wessels, R. (1988, March). The determinant of capital structure choice. Journal Of Finance, 43, 1-18. 